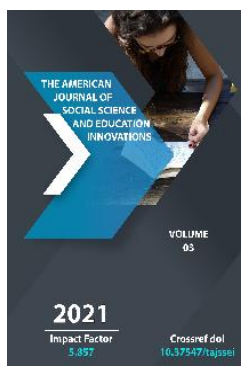

\title{
Scientific Project For Humanities Students
}

Rakhimov Adham Barat Oglu

Jizzakh Polytechnic Institute, Jizzakh City, Uzbekistan

Journal Website:

http://theamericanjour

nals.com/index.php/taj

ssei

Copyright: Original content from this work may be used under the terms of the creative commons attributes 4.0 licence.

\section{ABSTRACT}

This article covers issues such as "project", "project work" and the content of the research project for students of the social sphere, the importance of the research project in the teaching of foreign languages.

\section{KEYWORDS}

Student, social sphere, foreign language, project, research project, project structure.

\section{INTRODUCTION}

"Project work", "project" is defined as an approach in teaching foreign languages that complements the basic methods and which can be used at all levels, regardless of the age and abilities of the students. A "project" is effective when it goes beyond the classroom and is a natural extension of what happens in class. 
The project has the following characteristics:

- Topics relevant to students become the object of the project;

- The project provides for student-centered training, teaches to play the role of an advisor, guide;

- The project is executed in a spirit of cooperation, students work on their own in small groups, in a group where opinions, ideas, experience are exchanged;

- The project leads to the use of authentic materials and to the integration of skills, the analysis of information from various sources, including sources from real life;

- The project ends with a "product" (oral presentation, poster, visual aid, bulletin, report, presentation), but it is not the final product that is much more important, but the work process itself, which develops students' accuracy and accuracy in performing work at various stages of the project;

- The project has a potentially great motivation, inspires, aims at solving difficult problematic problems, stimulates and develops in students such qualities as confidence, purposefulness, improves cognitive, search activity and meaningful learning skills [1].

By structure, projects are usually divided into:

- Structural projects - developed, specialized, organized by the teacher in terms of topics, materials, methodology and presentation;

- Non-structural projects - completely developed by the students themselves;
- Semi-structural - planned and developed jointly by the teacher and students.

Projects can be related to:

- Real situations (booklet, travel agency in Europe);

- Simulations (debate about advantages and disadvantages ...);

- The interests of students (interviews at an international airport while traveling).

- Projects differ in the technology of collecting material and information sources:

- $\quad$ Research projects (work in libraries);

- Text projects (work with texts and literature, reports, newspaper materials, video, audio materials);

- Projects - correspondence communication with businessmen, schools, through letters, faxes, phone calls, e-mail;

- Projects - reviews - review of materials;

- Projects - contacts (meetings) - face-toface meetings with businessmen, leaders, individuals.

Projects also differ in the form of reporting:

- Projects in the form of finished products;

- Presentation projects (tastings, performances, shows, fairs);

- Organizational projects - planning and organizing the work of a club, an enterprise.

The project, regardless of the configuration, can be developed and implemented both in a 
short time and last several months, a full semester.

The project can be implemented individually or in small groups of 2-3 students, in a full academic group or with the involvement of students from other groups / specialties.

The following stages of a student research project can be distinguished:

1. Choosing a theme for the project.

2. Definition of the final result - "product" (brochures, multimedia presentations, etc.).

3. Structuring the project, drawing up a work plan, distribution of functions, responsibilities.

4. Collection of information.

5. Selection and analysis of information.

6. Design of the project, elimination of linguistic and technical problems.

7. Presentation of the final product.

8. Product evaluation. [2]

The details of the project depend to some extent on contextual factors, the purpose and objectives of the training program, and the resources available.

Academic preparation of students in the first year of study at a university in English can be associated with the development of projects determined by the students themselves, related to their future specialty.

Many projects focus on issues specific to their region and country and the nature of the training.
In general, the project methodology can be used in teaching English to students of both non-linguistic and linguistic specialties.

In the second case, special attention to the method of project work can be paid when teaching a foreign language for academic purposes, for special purposes, for professional purposes, in the university training of foreign language teachers, when conducting advanced training courses for teachers of English, German,

French and other languages.

When teaching EPP (English for Professional Purposes), for example, students majoring in "tourism", the project can be aimed at creating brochures, tourist brochures that arouse interest in individual attractions of the hometown. When studying the regional characteristics of English-speaking countries, students create bulletins with illustrations and classified information about the countries and cities in question.

When teaching ESP on international law, the project can be prepared in the form of a report, which contains a comparison of the American and Uzbek judicial systems, analysis and evaluation of the material of this course.

When reading academic courses, methods of teaching a foreign language, the use of projects in the study of individual topics allows students to deeper and comprehensively consider the material being studied, prepare visual aids in the form of tables, posters on this topic, as well as slides, audio and video presentations.

Active preparation for the competition of student projects, as a rule, begins in February, at the very beginning of the second semester of the academic year, which makes it possible to involve freshmen who have managed to join the educational process over the past period, as well as to acquire initial skills in 
working with literature, audio video products in the libraries of the university.

In our opinion, the most significant advantages of using the project methodology in foreign language classes are the following:

- Active involvement of students in the educational process, giving it a meaningful character, which, in turn, leads to the formation of deep knowledge and sustainable skills;

- The simultaneous development of all language skills: speech, listening, writing, reading;

- Development of cognitive, search skills of students;

- Increasing responsibility on the part of students for the result of their work;

- The use of a large number of authentic materials;

- Development of communication skills, cooperation in solving the problem;

- Shifting the center of attention in the learning process from the teacher to the student, which allows the student to act as a specialist competent in all the issues under consideration.

There is a connection between the student's motivation and the student's cognitive interest, which is the result of learning within a specific topic - on the one hand, and the student's ability to pass difficult material through himself, recall information and develop ideas further. Students become experts when they bring their knowledge into the material. As for the teacher, then on his part, in this case, a clear, complete instruction is required in the implementation of the project.

\section{REFERENCES}

1. Scientific projects submitted to the competition. Requirements for their registration // http://www.petropavl.kz/skoipkppk/page5 17_2.shtml

2. Bulent Alan, Fredericka L. Stoller. Maximizing the Benefits of Project Work in Foreign Language Classroom // English Language Forum. 2005. Vol.43, \# 4 